\title{
Penggunaan Portofolio dalam Penilaian Perkembangan Motorik Halus Anak Usia Dini di PAUD Al Wafi Kecamatan Selesai Kabupaten Langkat
}

\author{
Dwi Septi Anjas Wulan, \\ Dosen Program Studi PG PAUD FIP UNIMED \\ Jl. Williem Iskandar Pasar V Medan Estate, Medan, Sumatera Utara, 20371 \\ Email: dwiseptianjaswulan@unimed.ac.id
}

\begin{abstract}
Abstrak: Penelitian ini bertujuan untuk menganalisis pelaksanaan penilaian portofolio dalam penilaian perkembangan motorik halus anak di PAUD Al-Wafi Kecamatan Selesai Kabupaten Langkat. Penelitian ini menggunakan deskriptif kualitatif dalam penelitan deskripsi kuantitatif dan analisis kualitatif dalam satu kegiatan penelitian dengan subjek penelitian guru, dokumen pembelajaran dan hasil karya anak. Teknik pengumpulan data dengan analisis dokumen, pengamatan dan wawancara dan dokumentasi. Hasil penelitian menunjukkan bahwa guru di PAUD Al-Wafi Kecamatan Selesai Kabupaten Langkat sudah melakukan penggunaan penilaian portofolio dengan optimal dan baik. Dari analisis dokumen RPPH dan dokumen hasil karya yang dianalisis menjelaskan bahwa tahapan penilaian portofolio sudah dilaksanakan dengan baik. Penggunaan portofolio dalam penilaian perkembangan motorik halus anak dapat meningkatkan motivasi belajar anak dan meningkatkan proses penilaian yang efektif dikelas.
\end{abstract}

Kata Kunci : penilaian Portofolio, asesmen, motorik halus

\section{Pendahuluan}

Masa usia dini merupakan periode emas (golden age) bagi perkembangan anak untuk memperoleh proses pendidikan. Periode ini adalah tahun-tahun berharga bagi seorang anak untuk mengenali berbagai macam fakta di lingkungannya sebagai stimulans terhadap perkembangan kepribadian, psikomotor, kognitif maupun sosialnya. Anak usai 5-6 tahun, berbeda pada tahap perkembangan awal masa kanakkanak. Perkembangan merupakan suatu perubahan yang berlangsung seumur hidup dengan bertambahnya struktur dan fungsi tubuh yang lebih kompleks dalam kemampuan gerak, bicara dan bahasa serta sosialisasi dan kemandirian. Ciri-ciri pertumbuhan dan perkembangan anak antara lain: menimbulkan perubahan, berkolerasi dengan pertumbuhan, memiliki tahap yang berurutan dan mempunyai pola yang tetap. Perkembangan tersebut meliputi perkembangan fisik motorik, intelektual, bahasa, sosial-emosional. Seorang anak pada usia dini dari hari ke hari akan mengalami perkembangan, perkembangan tersebut berlangsung secara cepat 
dan sangat berpengaruh terhadap perkembangannya selanjutnya. Namun tentunya tiap anak tidak sama persis pencapaiannya, ada yang benar-benar cepat berkembang ada pula yang membutuhkan waktu agak lama.

Berdasarkan hasil pengamatan peneliti mendapatkan bahwasannya pelaksanaan penilaian portofolio belum sesuai dengan setiap tahapannya tidak dilaksanakan dengan baik, karena guru atau pendidik hanya melihat hasil akhir dari pembelajaran sehingga guru kurang memperhatikan setiap tahapan dalam penilaian portofolio yang sudah dirancang. Guru hanya memperhatkan hasil akhir pada setiap kegiatan yang dilakukan. Fakta ini juga dikemukakan oleh penelitian dari Soewandi (2005) menjelaskan bahwa ada beberapa kelemahan dari penilaian portofolio yang dialami oleh guru antara lain: guru memerlukan waktu ekstra untuk merencanakan dan melaksanakan penilaian dengan portofolio, guru memiliki kecenderungan untuk memperhatikan hanya pencapaian akhir. Jika hal ini terjadi, berarti penilaian proses tidak mendapatkan perhatian sewajarnya, Penilaian dengan portofolio memerlukan tempat penyimpanan dokumen yang memadai, apalagi jika jumlah peserta didik cukup besar. Guru juga mengalami kesulitan mengembangkan instrumen penilaian perkembangan anak usia dini. Kesulitan ini berkaitan dengan penjabaran indikator perkembangan sesuai dengan STTPA ke dalam deskriptor penilaian yang akan menghasilkan rubrik penilaian. Hal inilah yang menyebabkan guru hanya menilai aspek-aspek tertentu dari perkembangan anak yang dianggap mudah untuk dinilai seperti aspek agama-moral, kognitif, bahasa, dan seni kreativitas.

\section{Kajian Teori}

Richard (1989: 103) mengatakan bahwa keterampilan motorik halus (fine motor skill) merupakan keterampilan yang memerlukan kontrol dari otot-otot kecil dari tubuh untuk mencapai tujuan dari keterampilan. Secara umum, keterampilan ini meliputi koordinasi mata tangan. Keterampilan ini membutuhkan derajat tinggi dari kecermatan gerak untuk menampilkan suatu keterampilan khusus di level tinggi dalam kecakapan. Dalam hal ini Brewer (2007:20) menjelaskan "fine muscle control increases; can use hammer, pencil, scissors, copies geometric figures, cuts on lines, print some letters, pastes and glues, handness is well established." Keterampilan motorik halus seorang anak dapat dilihat dari ketangkasannya 
menggunakan palu, pensil, gunting, menggambar bentuk geometri, memotong sesuai garis, menempel dan mengelem dan gerakan yang mengandalkan dominasi tangan.

Sujiono (2008: 13) yang menyatakan bahwa perkembangan motorik dapat disebut sebagai perkembangan dari unsur kematangan dan pengendalian gerak tubuh. Menurut Susanto (2011 : 164) motorik halus adalah gerakan halus yang melibatkan bagian-bagian tertentu saja yang dilakukan oleh otot-otot kecil saja, karena tidak memerlukan tenaga. Namun begitu gerakan yang halus ini memerlukan koordinasi yang cermat.

Menurut Tseng dan Chow dalam Liu dkk bahwa (2015) Fine motor skills are essential in writing because they help form letters and numbers accurately and "can only be produced by proper timing and force control of coordinated arm, hand, and finger movement" Keterampilan motorik halus sangat penting dalam menulis karena membantu membentuk huruf dan angka secara akurat dan hanya bisa diproduksi pad waktu yang tepat melalui kontrol kekuatan gerakan tangan, tangan, dan jari yang terkoordinasi.

Allen dan Marrotz (2010:149-164) juga menambahkan bahwa bentuk keterampilan motorik halus anak usia 5-6 tahun antara lain anak sudah mampu (a) membangun rakitan tiga dimensi dengan menggunakan kubus-kubus kecil (meniru gambar atau model), (b) menggambar atau menulis berbagai bentuk dan huruf seperti kotak, segitiga, A, I, O, U, C, H, L, dan T, (c) menunjukkan pengendalian yang cukup baik pada pensil dan spidol; bisa mulai mewarnai di dalam garis, (d) menggunting garis secara tidak sempurna, (e) mengembangkan dominasi tangan (kanan/kiri) pada hampir seluruh kegiatan, (f) suka membuat karya seni; suka mengecat, membentuk sesuatu menggunakan lempung, menggambar dan mewarnai, dan berkreasi menggunakan kayu, (g) menggambar atau menjiplak tangan dengan benda lain, (h) melipat dan menggunting kertas menjadi bentuk yang sederhana, dan (i) mengikat tali sepatunya sendiri.

Berdasarkan uraian tersebut, maka dapat disimpulkan perkembangan motorik halus adalah perkembangan yang terlihat pada saat anak mapu mengendalikan gerakan- 
gerakan otot kecil yang berhubungan dengan koordinasi antara mata dengan jari dan lengan yang dilakukan secara bersama-sama saat melakukan suatu kegiatan atau aktifitas.

Asesmen atau penilaian adalah proses pengumpulan informasi yang digunakan untuk menggambil keputusan terkait kebijakan pendidikan, mutu program pendidikan, mutu kurikulum, mutu pengajaran, atau sejauh mana pengetahuan yang telah diperoleh seorang siswa tentang bahan ajar yang telah diajarkan kepadanya. Dalam hubungan dengan pengukuran, secara praktis penilaian didefinisikan sebagai penafsiran hasil pengukuran dan penentuan pencapaian hasil belajar.

Penilaian menurut Ralph Tyler 1950 dalam Yus (2011:39) merupakan sebuah proses pengumpulan data untuk menentukan sejauh mana, dalam hal apa, dan bagian mana tujuan pendidikan sudah tercapai. Griffin dan Nix 1991 mengemukakan bahwa penilian adalah kegiatan untuk menentukan nilai suatu program termasuk program pendidikan. Didalam penilaian terdapat kegiatan pengambilan keputusan. Astin 1993 mengemukakan penilaian merupakan suatu proses mengumpulkan informasi secara sistematik untuk membuat keputusan tentang individu. Brewer 1992 menyatakan penilaian adalah penggunaan sistem evaluasi yang bersifat komprehensif (menyeluruh) untuk menentukan kualitas dari suatu program untuk kemajuan dari seorang anak. Berarti penilaian itu harus dilakukan menyeluruh dari apa yang akan dinilai.

Penilaian tidak hanya mencakup satu aspek saja, tetapi harus bersifat menyeluruh.

Aspek yang dikembangkan yaitu kognitif, afektif, dan psikomotor. Dari penjelasan tersebut dapat disimpulkan bahwa penilaian merupakan sebuah proses atau kegiatan memperoleh informasi mengenai hasil belajar anak untuk menggambil sebuah keputusan dalam rangka untuk melakukan perlakuan selanjutnya pada masing-masing anak. Yus (2011:65) menjelaskan bahwa, "penilaian dilakukan dengan berbagai cara, secara garis besar metode penilaian dikelompokkan menjadi dua, yaitu tes dan nontes. Metode tes digunakan dengan alat penilaian berbentuk tes, sedangkan metode nontes digunakan dengan alat 
penilaian berbentuk observasi, pemberian tugas, percakapan, penilaian diri sendiri dan portofolio".

Portofolio berasal dari bahasa inggris "Portofolio" yang atinya dokumen atau surat-surat. Dalam hal ini pengertian portofolio adalah suatu kumpulan pekerjaan siswa dengan maksud tertentu dan terpadu yang siseleksi menurut panduanpanduan yang ditentukan. Arifin (2009:197) menyatakan bahwa "portofolio merupakan kumpulan dokumen berupa objek penilaian yang dipakai oleh seseorang, kelompok, lembaga, organisasi atau perusahaan yang bertujuan untuk mendokumentasikan atau menilai perkembangan suatu proses”. Ambara, dkk (2014:97) menjelaskan tentang,"penilaian portofolio juga merupakan penilaian berbasis kelas terhadap sekumpulan peserta didik yang tersusun secara sistematis dan teorganisir yang diambil selama porses pembelajaran dalam kurun waktu tertentu". Menurut Popham (1999) dalam Yus (2011:90) menjelaskan bahwa, "portofolio adalah pengumpulan pekerjaan seseorang secara sistematik. Berarti dengan fortofolio guru dapat mengoleksi karya seseorang berdasarkan aturan tertentu. Selanjutnya Popham (1999) menjelaskan bahwa portofolio digunakan untuk mengukur prestasi belajar anak yang bertumpu pada perbedaan individual. Berarti penilaian dengan portofolio dilakukan dengan membandingkan karya anak dari waktu ke waktu dengan dirinya sendiri”.

Dari penjelasan tersebut dapat disimpulkan bahwa pengertian portofolio adalah kumpulan karya-karya terpilih anak secara individu dalam satu periode tertentu. Maknanya adalah bahwa yang harus menjadi akumulasi dari segala sesuatu yang ditemukan anak dari topik tertentu haarus menggambarkan usaha terbaik anak dalam menjalankan tugas-tugas yang diberikan oleh guru.

\section{Metode Penelitian}

Data dianalisis dengan menggunakan statistik deskriptif dan analisis kualitatif dengan menghubungkan data yang ada. Responden penelitian adalah guru Taman Kanak-kanak Pengumpulan data dilakukan dengan menggunakan angket dan analisis dokumen yang terdiri dari RPPH, hasil karya anak dan catatan serta instrumen penilaian yang digunakan oleh guru. Angket yang digunakan pada penelitian ini untuk mengetahui bagaimana guru Taman Kanak-kanak dalam 
menerapkan assessmen autentik. Hasil angket yang diperoleh kemudian didokumentasikan dan dikategorisasikan menjadi empat kategori, yakni sangat tinggi, tinggi, sedang dan rendah dengan menggunakan rumus interval. Analisis dokumen dilakukan untuk mengetahui penilaian yang digunakan guru pada saat pembelajaran dari RPPH, hasil karya anak dan catatan serta instrumen penilaian yang digunakan oleh guru.

\section{Hasil Penelitian dan Pembahasan}

Berdasarkan hasil analisis dokumen dan diperkuat dengan wawancara dapat disimpulkan bahwa pada tahap persiapan meliputi menentukan tujuan penilaian portofolio, kemudian menentukan komponen, dan menentukan sistem penyimpanan. Peneliti melihat bahwa guru sudah melaksanakan penentuan tujuan penilian portofolio yang akan digunakan yaitu untuk melihat perkembangan seni dari peserta didik, dan melihat perkembangan kognitif dari peserta didik. Sehingga tujuan dari penilaian portofolio dapat terlaksanakan dengan baik melihat bagaimana perkembangan motorik halus anak.

Tahap menentukan format peneliti melihat bahwa guru belum membuat format dalam penilaian portofolio yang dilaksanakan. Guru hanya menggunakan lembar kerja apa yang dikerjakan anak, kegiatan apa yang dilaksanakan dalam pembelajaran. Peneliti tidak melihat bahwa guru menggunakan format. Guru tidak membuat format gambar atau hasil karya yang akan dikerjakan oleh guru terlebih dahulu sebelum diberikan atau diarahkan ke anak.

Kemudian pada tahap menentukan sistem penyimpanan, pada saat peneliti datang kesekolah PAUD Al Wafi untuk melihat bagaimana bentuk portofolio yang digunakan. Guru menggunakan map plastik yang berwarna biru kemudian map tersebut letakkan di dalam keranjang yang dimiliki setiap anak di kelas. Sehingga map portofolio anak tersusun rapi di atas keranjang atau wadah yang dijadikan sebagai loker anak.

Pada tahapan pelaksanaan penilaian portofolio peneliti melihat berdasarkan hasil wawancara dan analisis dokumen, pada tahap mengidentifikasi komponen, 
mengumpulkan dan menyusun karya. Guru memuat berbagai macam komponen yang dilaksanakan. Guru membuat catatan anekdot terhadap anak, guru membuat catatan dalam hasil pekerjaan anak, sehingga peneliti melihat bahwa di PAUD AlWafi guru sudah melaksanakan tahapan mengidentifikasi komponen dalam penilaian portofolio anak. Kemudian pada tahap mengumpul dan menyususn karya, guru menyusun dan mengumpulkan hasil karya anak kedalam map plastik dan diletakkan di dalam keranjang atau wadah sesuai dengan jumlah anak yang di dalam kelas. Guru menyusun karya anak berdasarkan tema dan tanggal yang dilaksanakannya dalam kegiatan pembelajaran. Hasil karya anak mengacu pada banyak variasi seperti kerajinan tangan anak, lembar kerja, gambar anak, dan proyek. Namun peneliti melihat bahwa guru lebih banyak atau lebih condong menggunakan lembar kerja dan gambar anak sebagai produk dalam portofolio siswa. Hasil karya anak berdasarkan wawancara yang dilakukan peneliti guru menjelaskan bawa lebar kerja yang digunakan guru berupa majalah kerja anak yang disediakan dari kepala sekolah yang mendapat subsidi dari dinas pendidikan kota Binjai dan ada beberapa yang dibeli sendiri. Lembar kerja yang dikerjaakan anak disesuaikan dengan RPPH yang sudah dirancang oleh guru kelas. Selain mengerjakan majalah lembar kerja anak, guru juga menggunakan hasil gambar anak dan mewarnai sejalan dengan tujuan penilaian portofolio dalam rancang RPPH yang sudah dipersiapkan oleh guru sehingga tujuan portofolio dapat terlaksanakan dengan baik. Produk yang dihasilkan anak bukan hanya lembar kerja atau majalah siswa tetapi hasil gambar dan mewarnai anak. Dalam mengembangkan kreativitas siswa dalam bidang seni, guru mengajak anaknya untuk menggambar dan mewarnai. Peneliti melihat bahwa di dalam dokumen portofolio anak yang dianalisi terdapat banyak majalah lembar kerja anak, buku menulis dan buku gambar anak. Hal ini dikemukakan juga dan didukung oleh penelitian Nursanti (2015) yang menyatakan sekolah tersebut juga masih sering menggunakan lembar kerja sehingga anak merasa bosan dan tidak bersemangat selain itu penyebab kurangnya kreativitas anak. Hal ini juga dikemukakan dalam penelitian dari Kurniawati (2018) menyatakan bahwa proses pembelajarannya juga belum efektif, pembelajaran yang dilakukan lebih monoton anak cenderung mengikuti intruksi guru, kegiatan membaca menulis dilakukan tidak melalui bermain 
sehingga kurang memanfaatkan alat permainan edukatif (APE) dalam kegiatan belajar, mereka juga kerap menggunakan buku majalah dan lembar kerja anak.

Pada tahap penilaian dalam menentukan nilai dokumen bahwa pendidik membuar daftar ceklis, dan rubrik yang dibuat pendidik. Guru juga menuliskan perkembangan anak sesuai dengan rubrik yang dibuat oleh guru itu sendiri, guru juga membuat daftar ceklis. Guru menuliskan setiap perkembangan anak dalam buku khusus yang disediakan oleh kepala sekolah agar guru melihat bagaimana perkembangan anak tersebut dilihat dari hasil pekerjaannya dari hari kehari berdasarkan rubrik yang sudah ditentukn guru. Penilaian yang dilakukan guru menggunakan ekspresi wajah, ekspresi wajah tersenyum lebar menggambarkan BSB (berkembang sangat baik), ekspresi wajah senyum menggambarkan kriteria BSH (berkembang sesuai harapan), ekspresi wajah datar menggambarkan kriteria MB (mulai berkembang), dan ekspresi wajah sedih mengambarkan BB (belum berkembang). Berkas portofolio dinilai guru pada saat anak selesai mengerjakan. Hal ini dikemukakan juga oleh penelitian dari Zahro (2015) menyatakah bahwa penggabungan data yang terkumpul melalui pengamatan yang ditulis dalam catatan anekdot maupun hasil karya anak diolah untuk melihat perkembangan hasil belajar anak. Hal ini ditangani oleh guru yang menangani anak tersebut dengan tujuan untuk melihat perkembangan terbaik yang dicapai anak. Hasil penggabungan data hasil belajar dapat dimasukkan ke dalam cheklist. Dan kriteria dalam daftar cheklist berdasarkan BB, MB, BSH, dan BSB. Hasil penelitian yang peneliti peroleh sesuai dengan yang dikemukakan oleh penelitian dari Dewi, dkk (2019) menyatakan bahwa prosedur pelaksanaan penilaian portofolio terdapat tiga tahapan yaitu: tahap persiapan, tahap pelaksanaan, dan tahap penilaian. Berikut ini merupakan tabel Pelaksanaan penilaian portofolio di PAUD Al-Wafi.

Tabel. 1 Pelaksanaan Penilaian Portofolio 


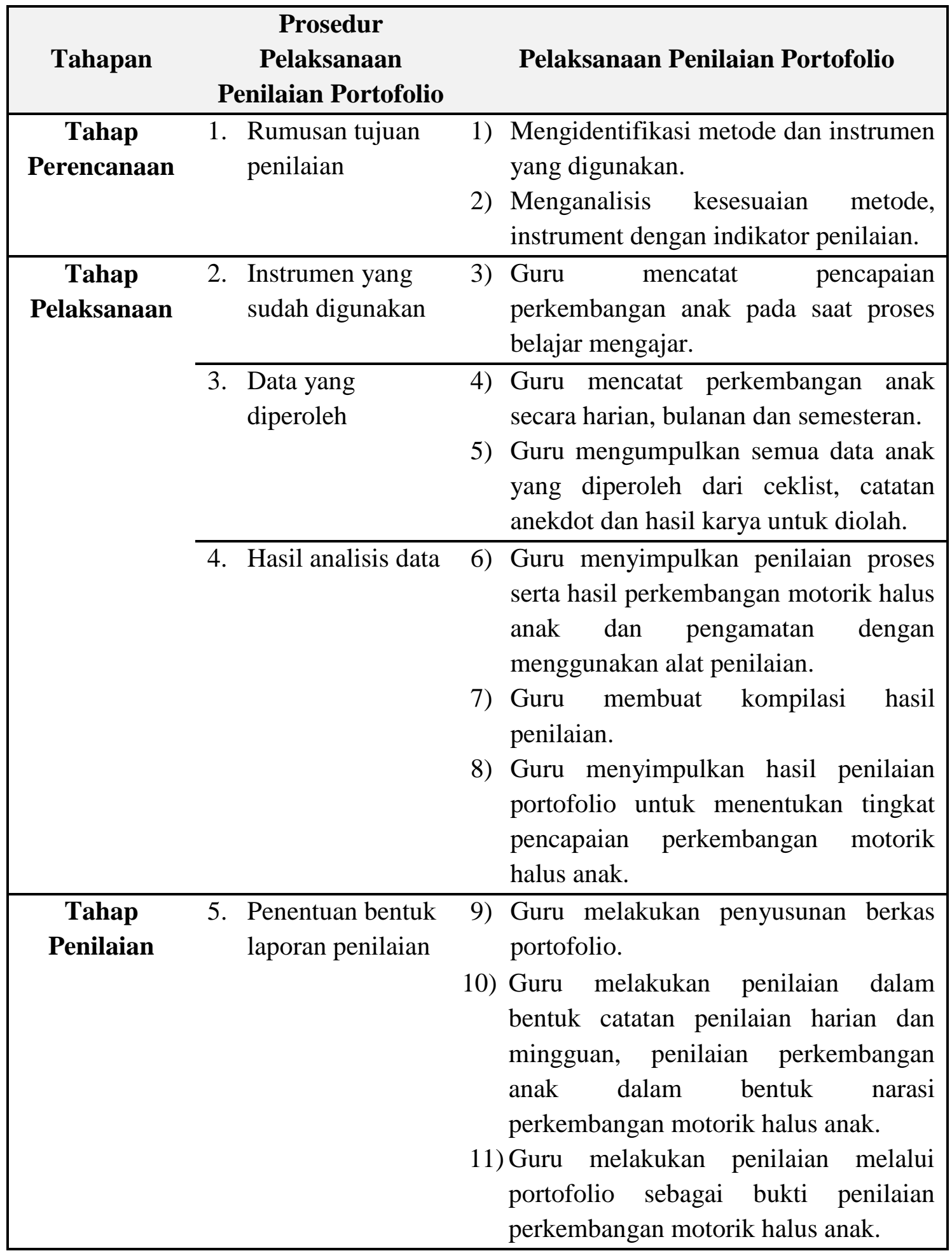

Berdasarkan hasil pengamatan analisis dokumen dan dipertegas kembali dengan hasil wawancara, peneliti mendapatkan hasil berdasarkan tabel di atas gambar hasil pekerjaan anak, gambar tersebut memilik makna yang sesuai dengan RPPH yang dibuat guru yaitu mengenal bagaimana gambar bentuk jarum suntik, apa saja kegunaan jarum suntik dalam bidang medis. Guru membuat makna dari 
tugas siswa dan menjelaskan kepada siswa makna dari tugas yang dikerjakan siswa. Makna dari tugas yang akan dikerjakan siswa tersebut merupakan makna yang sejalan dengan tujuan dari materi kegiatan yang mengembangkan ke-6 aspek perkembangan siswa. Sehingga analisis yang digunakan guru hanya sebatas tujuan dari pembelajaran saja dan tujuan dari materi kegiatan yang akan dilaksanakan. Sehingga analisis yang dilakukan tidak didukung oleh kriteria yang sudah dibuat oleh guru. Analisis dilakukan guru hanya mengalasisi hasil karya anak dan hasilnya dimasukkan kedalam daftar penilaian ceklis yang sudah disiapkan oleh guru. data yang diperoleh dibandingkan dengan kriteria yang ditetapkan oleh guru. Guru kelompok B menggunakan daftar cek, kemudian guru menghitung berapa tanda yang diperoleh yang diperoleh atau yang dimiliki anak setiap kemampuan. Jumlah tanda dibandingkan dengan kriteria, kalau lebih atau sama berarti berhasil. Kalau dibawah berarti nilainya belum berhasil. Dengan demikian guru hanya mendeskripsikan sesuai dengan data yang dieroleh dan membuat laporan kepada kepala sekolah pada waktu yang sudah disetujui oleh guru dengan kepala sekolah., Hal ini juga terlihat dari penelitian dari Palmin dkk (2019) menyatakan bahwa berdasarkan data hasil wawancara diperoleh informasi bahwa guru hanya menggunakan teknik checklist saja karena guru kesulitan menentukan teknik penilaian yang sesuai dengan kegiatan yang dilakukan anak, sehingga lebih sering hanya menggunakan satu teknik saja yaitu ceklis, sedangkan catatan anekdot dan hasil karya tidak digunakan.

\section{Simpulan}

Berdasarkan hasil penelitian dan pembahasan di atas, maka dapat diambil kesimpulan terhadap penelitian ini, yaitu: 1.Hasil analisis terhadap tahapan penilaian portofolio yang digunakan oleh TK Al-Wafi sudah dilaksanakan dengan baik sesuai dengan 3 tahapan. Tahapan persiapan, tahap pelaksanaan, dan tahap penilaian. Pada tahap menentukan format guru harus memperlihatkan hasil pekerjaan atau hasil karya yang sudah di buat oleh guru sendiri agar anak dapat melihat sebagai pedoman 2.Guru menggunakan kriteria yang belum dibuat sendiri secata tertulis. Guru hanya memiliki kriteria tetapi hanya didalam pikiran pada saat itu saja sehingga guru bisa memberikan nilai pada hasil pekerjaan anak. Guru hanya memiliki kriteria sesaat dalam saat tertentu dan menggunakan filing pada saat menilai hasil pekerjaan 
anak. Dalam pelaksanaan penilaian portofolio dalam menilai perkembangan anak terbukti efektif untuk mengoleksi hasil karya anak sebagai bukti perkembangan motorik halus anak selama di TK Al Wafi.

\section{Daftar Pustaka}

Ambara, Didith, dkk. 2014. Asesmen Anak Usia Dini. Yogyakarta: Graha Ilmu.

Arifin, Zainal. 2016. Evaluasi Pembelajaran Prinsip, Teknik, dan Prosedur. Bandung: Rosda.

Arikunto, Suharsimi. 2017. Prosedur Penelitian Satuan Pendekatan Praktik. Jakarta: Rineka Cipta.

Dewi, Puput, dkk. 2019. Penerapan Penilaian Portofolio dalam Asesmen Perkembangan Motorik Halus Anak di TK Se-Gugus Arjuna Kecamatan Jatipurno. Kumara Cendekia, Vol 7 No 1.

K Eileen Allen dan Lynn R Marrotz, Profil Perkembangan Anak Prakelahiran Hingga Usia 12 Tahun Edisi 5, (Jakarta: Indeks, 2010).

Magill, Richard A. (1989). Motor Learning Concepts and Applications. USA: C. Brown Publishers.

Jo Ann Brewer, Introduction To Early Childhood Education Preschool Through Primary Grades Sixth Edition (United State of Amerika: Pearson, 2007), h.20

Sugiono. 2017. Metode Penelitian Pendidikan Pendekatan Kualitatif, Kualitatif dan R\&D. Bandung: Alfabeta.

Yus, Anita, dkk. 2017. Models of Portfolio-Based Teaching as a Early Childhood Social Emotional Skills Development Strategy. Advances in Social Science, Education and Humanities Research, Vol 104.

Yus, Anita. 2011. Penilaian Perkembangan Belajar Anak Taman Kanakkanak.Jakarta: Kencana. 
